\title{
The Schizopoda and Isopoda collected by the "Huxley" from the north side of the Bay of Biscay, in August, 1906.
}

By

W. M. Tattersall, M.Sc.

I AM indebted to the courtesy of Dr. Allen for the opportunity of examining the collections of these two orders of Crustacea in the Huxley's material.

None of the species are new to science, and but few of them present any features worthy of remark. The chief interest of the collection lies in its bearing on the known geographical distribution of the species captured for, out of a total of twenty-eight, no fewer than sixteen are recorded for the first time from localities south of the British Islands, while only eight of the species have previously been recorded from the Bay of Biscay. The bathymetrical range of five of the species recorded has been considerably increased by this material.

A comparison of the following lists with those for the same orders collected by the Caudan expedition, reveals little that is common to the two, the explanation of which is probably that the Caudan was working in much deeper water and considerably south of the area explored by the Huxley. The results of the work done by the Hirondelle and the Travailleur and Talisman in the Bay of Biscay are not available for the orders now under consideration. The only other expedition which has worked in the Bay is the Research, but as that dealt entirely with plankton, the results are not strictly comparable with those of the Huxley. 
List of Species and the stations at which they occurred.

ScHIZOPODA.

$\begin{array}{lccccccccc}\text { Station } & \text { II } & \text { V } & \text { VII } & \text { VIII } & \text { IX } & \text { X } & \text { XI } & \text { XII } & \text { XIII } \\ \text { Longitude, N. } & 48^{\circ} 24^{\prime} & 47^{\circ} 48^{\prime} & 47^{\circ} 36^{\prime} & 47^{\circ} 30^{\prime} & 48^{\circ} 7^{\prime} & 48^{\circ} 7^{\prime} & 48^{\circ} 10^{\prime} & 48^{\circ} 7^{\prime} & 48^{\circ} 7^{\prime} \\ \text { Longitude, W. } & 6^{\circ} 28^{\prime} & 7^{\circ} 46^{\prime} & 7^{\circ} 31^{\prime} & 7^{\circ} 31^{\prime} & 8^{\circ} 13^{\prime} & 8^{\circ} 13^{\prime} & 8^{\circ} 11^{\prime} & 8^{\circ} 13^{\prime} & 8^{\circ} 13^{\prime} \\ \text { Fathoms } & 75 & 109 & & & & & \end{array}$

Euphausia Miilleri

Meganyctiphanes norvegica

Nyctiphanes Couchi

Nematoscelis megalops

Lophogaster typicus

Siriella norvegica

Haplostylus Normani

Anchialina agilis

Amblyops abbreviata

Paramblyops rostrata

Pseudomma affine

Mysideis insignis

Mysidopsis didelphys

Leptomysis gracilis .

Leptomysis sp.

Mysidetes Farrani

Boreomysis arctica

Schistomysis ornata

IsOPODA.

Aega Strömii .

Rocinela damnoniensis

Cirolana borealis

Cirolana Hanseni

Eurydice truncata

Astacilla longicornis

Ianira maculosa

Munna Boecki

Eurycope longipes .

Aspidophryxus peltatus

\section{SCHIZOPODA.}

Of the eighteen species of this order represented in the collection, none can be described as new, though two specimens of the genus Leptomysis cannot be referred satisfactorily to any described form. They are, however, very closely allied to $L$. gracilis, and I await further material before deciding the point. The depth at which they were found is unusual for the genus.

Only four of these species have been previously recorded from the Bay of Biscay, viz., Euphausia Mülleri, Meganyctiphanes norvegica, Nematoscelis megalops, and Lophogaster typicus.

Four other species, Nyctiphanes Couchi, Haplostylus Normani, Anchialina agilis, and Boreomysis arctica are, however, known from 
the Mediterranean, and their occurrence in the Bay of Biscay merely fills, in part, the gaps existing in their geographical distribution. The remaining species have not hitherto been recorded from localities south of the British and Irish area (Leptomysis gracilis is, however, known from the French side of the English Channel). The majority of them are deep water forms, which recent work has shown to be more or less abundant off the west coast of Ireland on the fringe of the Atlantic slope, and it was only natural, therefore, to expect that their known distribution would be considerably extended when the slope was further explored to the south.

Siriella norvegica and Schistomysis ornata are here recorded from depths greater than any at which they have up till now been taken, while the capture of no fewer than one thousand specimens of Euphausia Mülleri and eighty-three of Lophogaster typicus in surface hauls are features worthy of special note.

The records of Paramblyops rostrata and Mysidetes Farrani are of interest, since these two species have only lately been described from material collected in deep water off Ireland.

\section{SCHIZOPODA.}

\section{FAMILY EUPHAUSIIDAE.}

Euphausia Mülleri, Claus.

Station VIII. $c a$. one thousand specimens, up to $22 \mathrm{~mm}$.

Station X. Twenty-eight specimens, 5-11 mm.

The occurrence of no fewer than one thousand specimens of this species in a surface haul, Station $\mathrm{X}$, is worthy of special note.

\section{Meganyctiphanes norvegica (M Sars).}

Station VIII. Five specimens, $14-28 \mathrm{~mm}$.

Station X. $c a$. three hundred specimens, $11-33 \mathrm{~mm}$.

Station XII. Twenty-two specimens, 17-34 mm.

\section{Nyctiphanes Couchi (Bell).}

Station X. $c a$. two hundred specimens, 7-17 mm.

Nematoscelis megalops, G. O. Sars.

Station VIII. Two specimens, 10 and $11 \mathrm{~mm}$.

Station X. Thirty-two specimens, $10-18 \mathrm{~mm}$. 


\section{FAMILY LOPHOGASTRID尼.}

Lophogaster typicus, G. O. Sars.

Station V. Two females, 20 and $22 \mathrm{~mm}$.

Station IX. Two females, $21 \mathrm{~mm}$.

Station X. Eighty-three specimens, 5-10 mm.

Station XI. One female, ovigerous, $21 \mathrm{~mm}$.

The occurrence at Station $\mathrm{X}$ of no fewer than eighty-three specimens of this species in a surface haul is a feature of great interest. L. typicus is regarded as essentially a bottom living form, though Holt and Tattersall * have recently recorded a specimen from a haul made at 44 fathoms, over a depth of 136 fathoms. This latter specimen was a gravid female, in which the young were ready to be liberated from the brood pouch. The probable fact is that $L$. typicus, in its normal adult condition, is a true bottom haunting form, but that the female rises to the surface to liberate the young and thus to ensure a wide distribution. The haul at Station $\mathrm{X}$ above supports this view, since all the specimens are small, and only two or three of the very largest have assumed quite adult form.

\section{FAMILY MYSID尼.}

Siriella norvegica, G. O. Sars.

Station V. One male, $19 \mathrm{~mm}$.

Two females, 14 and $17 \mathrm{~mm}$.

Station XI. Five males, 17-19 mm.

Two females, 15 and $19 \mathrm{~mm}$.

Haplostylus Normani (G. O. Sars).

Gastrosaccus Normani, G. O. Sars; Middlehavet's Mysider, p. 65; Pls. XXIV, XXV, 1876.

Station X. Fifteen males, 6-8 mm.

Eleven females, 5-11 $\mathrm{mm}$.

These specimens differ in one important respect from the description and figures given by Sars. Without exception, they have the hinder margin of the carapace furnished with two dorsal, upwardly and forwardly, directed lobes. The absence of lobes from the hinder margin of the carapace was one of the characters on which Kossmann separated the genus Haplostylus from Gastrosaccus. The present examples, however, agree exactly with $H$. Normani in the structure of the antennules, the length, form and armature of the telson, and

* Holt and Tattersall, "Fisheries, Ireland, Sci. Invest., 1904 V., [1906]." 
especially in the rudimentary inner branch to the third pleopods of the male and the curiously twisted rami of the second pleopods of the same sex.

It is curious to note in this respect that Holt and Beaumont, writing of Gastrosaccus sanctus from the west of Ireland, * remark: "most of the specimens from Bofin have practically no trace of the upturned processes of the hind margin of the carapace, though agreeing in other respects with the type." From these observations it would seem that the presence or absence of lobes is a character which cannot be relied on either for generic or specific separation, but the point is obviously one that requires further investigation. In the meantime, the present specimens agree so well with $H$. Normani in other respects, that I provisionally record them here as that species.

Anchialina $\dagger$ agilis (G. O. Sars).

Station $X$. Ten males, 6-9 mm.

Twenty-eight females, $6-9 \mathrm{~mm}$., most of them ovigerous.

Amblyops abbrieviata, G. O. Sars.

Station XII. Fifteen males, $12-16 \mathrm{~mm}$.

Sixteen females, $12-16 \mathrm{~mm}$.

Paramblyops rostrata, Holt and Tattersall.

Station IX. One female, head and thorax only.

Pseudomma affine, G. O. Sars.

Station XII. Two males, $11 \mathrm{~mm}$.

One female, $11 \mathrm{~mm}$.

Mysideis insignis, G. O. Sars.

Station IX. One female, $25 \mathrm{~mm}$.

Station XII. Ten males, $14-20 \mathrm{~mm}$.

Twenty-six females, 9-22 mm.

Mysidopsis didelphys (Norman).

Station V. One male, $13 \mathrm{~mm}$.

A specimen of the Isopod parasite, Aspidophryxus peltatus, G. O. Sars, was found attached to the basal joint of the left antennule.

Leptomysis gracilis, G. O. Sars.

Station X. One female, $10 \mathrm{~mm}$.

* Holt and Beaumont, Sci. Trans. Royal Dublin Soc., Series ii., Vol. vii., Pt. vii, 1900.

† Anchialina, Norman for Anchialus, G. O. Sars. See Norman and Scott, "Crustacea of Devon and Cornwall," London, 1906, p. 24. 


\section{Leptomysis sp.}

Station XI. One male, $11 \mathrm{~mm}$.

One female, $11 \mathrm{~mm}$.

These two specimens differed from $L$. gracilis (1) in having the dermis quite smooth instead of hispid; (2) the rostrum is quite short, and does not extend beyond the eyestalks, whereas in $L$. gracilis it is produced into a broadly triangular acutely pointed plate, which extends beyond the middle of the basal joint of the antennules. Otherwise they agree perfectly with normal specimens of $L$. gracilis, and it seems better to await further material before deciding whether they represent a hitherto undescribed form, or are merely abnormal specimens of L. gracilis.

\section{Mysidetes Farrani (Holt and Tattersall).}

Station XII. Four females, $18 \mathrm{~mm}$.

Boreomysis arctica (Kröyer).

Station XII. Two males, 15 and $18 \mathrm{~mm}$.

One female, $14 \mathrm{~mm}$.

Schistomysis ornata (G. O. Sars).

Station V. Two males, $14 \mathrm{~mm}$.

Eight females, $12-15 \mathrm{~mm}$.

Station XI. Three females, $14 \mathrm{~mm}$.

Both the stations at which these species occur are over 100 fathoms in depth. This depth is most unusual for the species, the greatest depth at which it has previously been captured being 50 fathoms. I cannot, however, at present find any substantial difference between these specimens and those from shallower water, and I am, therefore, obliged to consider them as belonging to the same species.

\section{ISOPODA.}

In all ten species of Isopoda are here recorded from the material collected by the Huxley. Of these only four have hitherto been found in the Bay of Biscay, viz., Cirolana borealis, Cirolana Hanseni (the type specimen of which was dredged by the Caudan expedition a little further south of the area explored by the Huxley), Eurydice truncata, and Ianira maculosa.

The remaining six species have not been recorded from localities south of the British and Irish marine area, so that the present records indicate the most southerly limit of their known geographical range.

With regard to the bathymetric range of the species, I am not 
aware that Ianira maculosa, Munna Boecki, and Astacilla longicornis have up till now been recorded from greater depths than 400 fathoms, so that the vertical distribution of all three has been extended as a result of the present material. Ianira maculosa was only found at Stations VIII and XIII, and from Professor Hickson's report on the Alcyonaria of the Huxley's cruise it was at both these stations that the majority of the Alyconaria were taken. In shallow water Ianira maculosa is very frequently found in considerable numbers crawling over colonies of Alcyonium digitatum, and in all probability the specimens in the present collection were clinging to the Alcyonarians found on the same grounds. Eurycope longipes is a species only recently described from specimens found off the west coast of Ireland on the edge of the Atlantic slope. Its occurrence further south on the same slope, while interesting, is only naturally to be expected.

\section{FAMILY ÆEGID压.}

Æga Strömii, Lutken.

Station XII. Three specimens.

\section{Rocinela damnoniensis, Leach.}

Station IX. One specimen.

Station XII. Four specimens.

\section{FAMILY CIROLANID疋.}

Cirolana borealis, Lilljeborg.

Station II. One specimen.

Station V. One specimen.

Station IX. Four specimens.

Station XII. Twelve specimens.

Cirolana Hanseni, Bonnier.

Station XIII. One specimen.

Stebbing, in his report on Professor Herdman's Ceylon Isopoda, suggests that this species should be referred to his genus Hansenolana, while Hansen, in his recent revision of the European members of the genus, still retains in it the genus Cirolana. The present specimen measures only $3 \mathrm{~mm}$., and is therefore smaller than Hansen's largest specimens, which was $4.2 \mathrm{~mm}$, and which Hansen thought to be still immature. As it is obvious that adult specimens are necessary before the correct genus for the species can be determined, I follow Hansen in retaining it in its original genus, Cirolana, for the present.

Eurydice truncata (Norman).

Station X. Fifty-three specimens. 
FAMILY ARCTURIDEE.

Astacilla longicoris (Sowerby).

Station 1I. One specimen.

Station XII. Sixteen specimens.

Station XIII. One specimen.

FAMILY IANIRID尼.

Ianira maculosa, Leach.

Station VII. Five specimens.

Station XIII. Thirteen specimens.

FAMILY MUNNID压.

Munna Boecki, Kröyer.

Station VII. T'wo specimens.

FAMILY MUNNOPSIDÆ.

Eurycope longipes, Tattersall.

Station XII. Three specimens.

\section{FAMILY DAJIDE.}

Aspidophryxus peltatus, G. O. Sars.

Station V. One specimen on the basal joint of the left antennule of Mysidopsis didelphys (Norman).

Both Sars and myself have recorded this parasite from the antennules of Mysidopsis didelphys, while I have also noted it on the same host from the more normal position for such parasites, viz., the dorsal surface of the thorax. 